\title{
An Analysis of Trade Integration in the Commonwealth of Independent States Region
}

\author{
Nuray Terzi, Marmara University \\ Erdem Turgan, Marmara University
}

\begin{abstract}
Most of the countries in Eurasia have significantly re-integrated with the global economy. Economic integration of Eurasia carries a global significance, especially in CIS region. Economic integration proceedes in different areas. One of the major areas is trade integration. Further trade integration can depend on different factors. The aim of this article is to identify trends in the trade integration of the CIS by explaining changes in the commodity composition of foreign trade, and by providing an insight into the trade policy, transport system and trade facility of the CIS region.
\end{abstract}

JEL Codes: F15, F13

\section{Introduction}

In today's economically integrated world, trade matters more than ever before. Most of the countries in Eurasia have significantly re-integrated with the global economy. Economic integration of countries has the potential to improve the economic efficiency and welfare of countries. In this context, economic integration of Eurasia carries a global significance, especially in CIS region. Economic integration process can proceede in different areas. One of the major areas is trade integration. A country's comparative advantage in international trade can vary significantly overtime not only due to differing rates in the accumulation of production factors or changes in technology, but also due to increased trade integration of other countries. The progress of trade integration can be influenced by political and economic forces. Further trade integration can depend on different factors in CIS region. The aim of this article is to to identify trends in the trade integration of the CIS. Following section gives the growth and composition of trade in CIS region. Next section analyzes trade integration in CIS region by explaining trade policy, transport system and trade facility. Last section provides a conclusion.

\section{The Characteristics of Trade in CIS Region}

The Table 1 shows that growth in export takes place among CIS and with the world. Since 2000 , the growth in export in CIS has increased. CIS countries exported around $\$ 137$ billion worth of merchandise to other CIS countries, but exported $\$ 521$ billion to the world in 2008 .

\begin{tabular}{|l|r|r|r|r|r|}
\hline & $\mathbf{2 0 0 0}$ & $\mathbf{2 0 0 1}$ & $\mathbf{2 0 0 2}$ & $\mathbf{2 0 0 3}$ & $\mathbf{2 0 0 4}$ \\
\hline World & 77,280 & 91,298 & 100,114 & 133,957 & 181,541 \\
\hline Among CIS & 29,053 & 32,103 & 30,361 & 39,842 & 54,968 \\
\hline & $\mathbf{2 0 0 5}$ & $\mathbf{2 0 0 6}$ & $\mathbf{2 0 0 7}$ & $\mathbf{2 0 0 8}$ & \\
\hline World & 223,673 & 291,918 & 397,418 & 521,248 & \\
\hline Among CIS & 61,728 & 78,079 & 70,085 & 137,099 & \\
\hline
\end{tabular}

Table 1. Growth in Exports of CIS, 2000-2008, Million US Dollars. Source: UNCTAD

In CIS, trade structure in export is overwhelmingly concentrated in fuels (64\%) while trade structure in import is mainly concentrated in traditional non-energy areas, such as machinery and transport equipment $(40 \%)$, other manufactured goods $(21 \%)$, primary commodities $(15 \%)$ fuels $(\% 11)$ and chemical products (10\%) (Graph 1). 

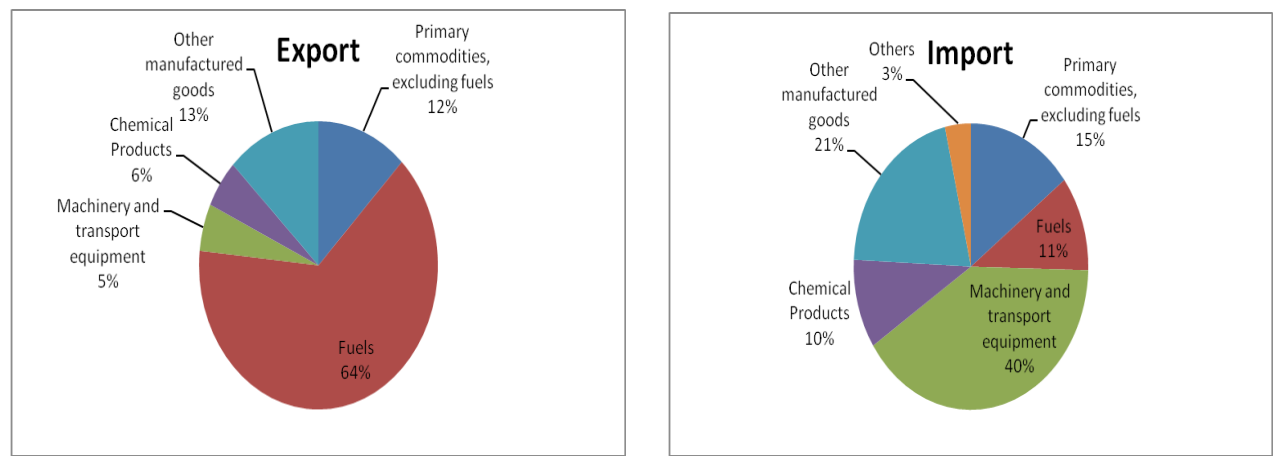

Figure 1. Trade structure by product group in CIS, 2008. Source: UNCTAD.

\section{Trade Integration in CIS Region}

Three main factor is important for further trade integration in CIS. First, trade policy of the countries in the region; second, development of transport system; and third, and trade facilitation across borders. Following section explains these three factors.

\subsection{Trade Policy}

Accession to the World Trade Organization (WTO) has the potential to impact greatly on the economies of member countries. On the one hand acceding countries make commitments to liberalize their markets by reducing tariffs and undertaking a variety of trade reforms. While consumers may gain from lower prices on imported goods, and acceding countries can use WTO membership to better position themselves to attract private investment flows, there are broad implications for domestic productive capacity in the main economic sectors agriculture, industry and services - as well as for growth, human development and poverty reduction. In this regard, critical challenges and opportunities face the 12 Commonwealth of Independent States (CIS) countries, half of which acceded to the WTO relatively recently with the other half in the process of negotiating accession (only Turkmenistan has not applied). (Table 2) They need to join with other countries to strengthen their bargaining position [2,3]

\begin{tabular}{|l|c|l|}
\hline & Application & Current Status \\
\hline Armenia & Nov-93 & Joined in 2003 \\
\hline Azerbaijan & Jul-97 & Ongoing negotiations \\
\hline Belarus & Sep-93 & Ongoing negotiations \\
\hline Georgia & Jul-96 & Joined in 2000 \\
\hline Kazakhstan & Jan-96 & Ongoing negotiations \\
\hline $\begin{array}{c}\text { Kyrgyz } \\
\text { Republic }\end{array}$ & Feb-96 & Joined in 1998 \\
\hline Moldova & Nov-93 & Joined in 2001 \\
\hline Russia & Jun-93 & Ongoing negotiations \\
\hline Tajikistan & May-01 & Ongoing negotiations \\
\hline Turkmenistan & $\ldots$ & $\ldots$ \\
\hline Ukraine & Nov-93 & Joined in 2008 \\
\hline Uzbekistan & Dec-94 & Ongoing negotiations \\
\hline
\end{tabular}

Table 2. WTO Accession Status of the CIS, 2010 [3]

Although WTO membership is a key element of global and regional integration for trade policy, their integration into the world economy and in Eurasia still lacks for now an important impetus (World Trade Organization).

Trade integration can also be pursued on a purely bilateral or regional basis. Table 3 shows 
the bilateral free trade agreements in CIS. Despite their proliferation, in the past many CIS preferential trade agreements remained agreements on paper only. There are several reasons for this. First, the coverage is limited and unclear, which made the agreements either ineffective or irrelevant. Sometimes the most sensitive goods were excluded (e.g., gas and oil for Kazakhstan and the Russian Federation). Exemptions and exceptions were not harmonized across countries and were usually granted on an ad hoc basis, which introduces uncertainties in their application. Second, because these arrangements provide a mechanism to allocate rents, there has been a rise in conflicts of interests, trade disputes, and retaliation, delaying or blocking the implementation of some agreements. Third, the costs of enforcing rules of origin are often higher than the benefits associated with a preferential tariff regime. Therefore, importers often forgo claiming the preferential rates. Fourth, because regional institutions were absent in the past, the regional trade agreements had to be self-enforcing, which weakened their implementation. Finally, the lack of harmonization in levying the value-added tax (VAT) in the past has resulted in numerous trade disputes and provoked suspension of the agreements on particular issues (Tumbarello, 2005).

\begin{tabular}{|c|c|c|c|c|c|c|c|c|c|c|c|c|}
\hline & $\begin{array}{c}\text { Arm } \\
.\end{array}$ & Azer. & Bel. & Geo. & Kaz. & Kyr. & Mol. & Russ & Taji. & Tur. & Ukr. & Uzb. \\
\hline Arm & $*$ & & & 1998 & 2001 & 1994 & 1993 & 1993 & & 1996 & & \\
\hline Azer & & $*$ & & 1996 & 1997 & & 1995 & 1992 & & 1996 & 1995 & 1996 \\
\hline Bel. & & & $*$ & & & & 1993 & 1996 & 1998 & & 1996 & 1993 \\
\hline Geo. & 1995 & 1998 & & $*$ & 1999 & & 1998 & 1994 & & 1996 & 1996 & 1995 \\
\hline Kaz. & & 1997 & 2001 & 1999 & $*$ & 1995 & 1995 & 1992 & & & & 1997 \\
\hline Kyr. & 1994 & & & & 1995 & $*$ & 1995 & 1993 & & & 1998 & 1998 \\
\hline Mol. & 1993 & 1995 & 1993 & 1998 & 1995 & 1995 & $*$ & 1993 & & 1993 & 1995 & 1995 \\
\hline Russ & & 1992 & 1996 & 1994 & 1992 & 1993 & 1993 & $*$ & & & 1993 & 1992 \\
\hline Taji. & & & 1998 & & & & & & $*$ & & & 1996 \\
\hline Tur. & 1996 & 1996 & & 1996 & & & 1993 & & & $*$ & & 1996 \\
\hline Ukr. & & 1995 & 1996 & 1996 & & 1998 & 1995 & 1993 & & & $*$ & 1994 \\
\hline Uzb. & & 1996 & 1993 & 1995 & 1997 & 1998 & 1995 & 1992 & 1996 & 1996 & 1994 & $*$ \\
\hline
\end{tabular}

Table 3. Bilateral Free Trade Agreements in CIS. Source: Tumbarello, 2005.

The CIS countries, because of their central location at the heart of the Eurasia region, are particularly important for permitting and facilitating regional trade integration Eurasia-wide. Table 4 shows the regional trade agreements involving CIS countries. Various reviews of regional trade policy and agreements in the CIS have shown that the high frequency of bilateral, regional and global trade agreements in the CIS, while in principle to be welcome as a recognition of the importance of regional trade integration, in practice has not yet led to effective trade cooperation within the CIS. The principal reasons are two-fold: One reason is the complexity of the overlapping trade agreements which leads to unimplementable trade relations among countries in the region. The second reason is that most of the agreements have actually not been implemented or enforced in practice, either due to a lack of political readiness for cooperation and integration, or because of the weakness of administrative capacity and high incidence of corruption in implementing national trade policies in many of the CIS countries (WTO).

\begin{tabular}{|c|c|c|c|}
\hline CACO (2002) & EAEC (2000) & UES (2003) & GUAM(1997) \\
\hline Russia, & Russia, Kazakhstan, & Ukraine, Belarus, Russia & Georgia, \\
Kazakhstan, & Kyrgystan, Tajikistan, & Kazakhstan, Kyrgystan, & Ukraine, \\
Kyrgystan, & Belarus & Tajikistan & Azerbaijan, \\
Tajikistan, & & & Moldova \\
Uzbekistan & & & \\
\hline
\end{tabular}

Table 4. Regional Trade Agreements Involving CIS Countries.. Source: UNDP Poverty Report 
In addition, some efforts at regional cooperation have been made in the last 10 years and various regional organizations have been created to support these efforts such as SCO, EurasEC, ECO, CAREC, SPECA, etc. (Table 5). However, they remain mostly quite ineffective. Significant efforts would be needed to convert them into an effective institutional framework supporting regional cooperation and integration of Central Asia (Linn, 2009).

\begin{tabular}{|c|c|c|c|c|}
\hline SCO (1996) & $\begin{array}{c}\text { EurAsEC } \\
(2000)\end{array}$ & ECO (1992) & CAREC (1997) & SPECA(1998) \\
\hline China & Belarus & Afghanistan, & Afghanistan, & Kazakhstan \\
Kazakhstan & Kazakhstan & Azerbaijan & Azerbaijan, China, & Kyrgyzstan \\
Kyrgyzstan & Kyrgyzstan & Iran, Kazakhstan & Kyrgyzstan, & Tajikistan \\
Russia & Russia & Kyrgyzstan, & Mongolia, & Turkmenistan \\
Tajikistan & Tajikistan & Pakistan & Tajikistan, & Uzbekistan \\
Uzbekistan & Uzbekistan & Tajikistan, Turkey & Uzbekistan, & Afghanistan \\
& & Uzbekistan & Mongolia, EBRD, & \\
& & & IMF, IDB, ADB, & \\
& & & UNDP,World Bank & \\
\hline
\end{tabular}

Table 5. Regional Organizations Involving CIS Countries. Source: Linn, and Pidufala (2009).

\subsection{The Integration of the Transport System}

The integration of national transport systems is key to the of most of the obstacles that restrict region's attempts to encourage greater use of its international transport corridors for transit. The post-Soviet space has a number of integration groups whose main aim is to overcome these physical and non-physical barriers such as CIS integration initiatives, EurAsEC initiatives, and initiative 1520 (Vinokurov et.al., 2009).

CIS integration initiatives The CIS is coordinating the integration of the transit and transport sectors of EurAsEC member countries. The CIS' transport policy identifies the following priorities[8]:In accordance with the need to promote liberalisation and economic reform, all CIS governments adopt the agreed transport policy. The policy aims to create a common market to which all operators have equal access; to implement an agreed tariff and tax policy; to preserve and extend unified technical and technological standards for the transport sector; and to maintain a unified approach to cooperation with third countries and international organisations; the extension and harmonisation of transport laws by the legislature of the CIS.

EurAsEC initiatives EurAsEC's purpose is to develop Unified Transport System (UTS) and a Transport Union of its member countries. EurAsEC countries(Belarus, Kazakhstan, Kyrgyzstan, Russia and Tajikistan) are committed to jointly pursuing the following goals: [8] Coordination of activities aimed at developing the international transport corridors linking European and Asian countries; the development of transport infrastructure and standardisation of technical and technological parameters across all EurAsEC transport corridors; a coordinated policy to attract foreign investment in transport corridors; refining the legal framework regulating the crossing of borders in EurAsEC; a policy of harmonised tariffs and charges for freight and passenger transport, crossing borders, use of infrastructure; encouraging the establishment of joint ventures engaged in international freight and passenger transportation and forwarding services; coordinating activities to enhance traffic and cargo safety and protect the environment; identifying opportunities to improve multi-modal shipments; finding the optimal location for and building new international logistics centres.

Initiative 1520 In May 2006, the first international 1520 Strategic Partnership rail industry forum was held in Sochi. The forum was created to discuss transport integration in the seventeen countries which use the $1520-\mathrm{mm}$ railway gauge. By the end of 2008, three such forums had been held in Russia. The forums include round-table and panel discussions on a 
wide range of administrative and technical issues, analysts' reports and potential solutions. The forums attract delegates not only from the "1520 Area", but also from Western Europe and the APR, who recognise the huge intercontinental importance of the 1520-mm gauge network and the investment opportunities that the region's transport system represents [8].

\subsection{Trade Facilitation}

According to the World Trade Organization, trade facilitation is the process of "simplification and harmonization of international trade procedures" covering the "activities, practices, and formalities involved in collecting, presenting, communicating and processing data required for the movement of goods in international trade." It relates to a wide range of activities at the border, such as import and export procedures; transport formalities; and payments, insurance, and other financial requirements (Roy,and Banerjee, 2010). Nevertheless, free trade among the CIS is not, as yet, generalized. Non-preferential tariff rates, therefore, maintain all their importance for trade flows, even within the region. As Table 6 below shows, tariffs are still relatively high, not least in the Russian Federation, which is by far the region's largest importer and has tariffs averaging over $10 \%$.

\begin{tabular}{|l|c|c|}
\hline Country & Tariff Year & Simple Average \\
\hline Armenia & 2001 & 3.3 \\
\hline Azarbaijan & 2002 & 10.1 \\
\hline Belarus & 2002 & 11.5 \\
\hline Georgia & 1999 & 9.9 \\
\hline Kyrgyzstan & 2002 & 8.2 \\
\hline Moldova & 2001 & 5.1 \\
\hline Russia & 2002 & 10.3 \\
\hline Tajikistan & 2002 & 8.0 \\
\hline Turkmenistan & 2002 & 5.3 \\
\hline Ukraine & 2002 & 7.9 \\
\hline Uzbekistan & 2001 & 10.6 \\
\hline CIS Average & & $\mathbf{8 . 8}$ \\
\hline
\end{tabular}

Table 6. Simple Average of Tariff. Source: UN, 2005

In addition to tariffs, a number of other obstacles to trade among the CIS countries appear not to have been sufficiently addressed, in spite of the existence of Free Trade Agreements (FTA) For an FTA to function, the elimination of customs duties is not sufficient. Moreover, implementation continues to lag behind, and significant barriers to trade in the CIS region remain. Longer trade routes, insufficient transport infrastructure, customs clearance and transit fees, lengthy and inefficient customs procedures, unofficial payments, need for a modern information system are the other various barriers to trade in the region[10].

\section{Conclusion}

In conclusion, CIS countries have increased their important in Eurasia. The level of export in CIS region has grown and trade structure in export is concentrated in fuels while trade structure in import is concentrated in machinery and transport equipment, primary commodities fuels and chemical products. Although WTO membership is a key element for trade integration for trade policy, their integration into the world economy and in CIS still lacks an important impetus. Many of them is outside of WTO; and bilateral and regional agreements remain mostly ineffective. Several initiativies try to provide the integration of national transport systems. However, they need to develop. In terms of trade facilitation, CIS region has some programs to improve trade facilitation but they still has some problems. In sum, CIS has significant position in a global context, but further trade integration is possible if it is supported by efficient trade policy, improved transport system, and enhanced trade facilitation. 


\section{References}

- Linn, J.2009. "Connecting Central Asia with the World", First Eurasian Emerging Market Forum, Gerzensee, Switzerland, Jan 31-Feb 2.p.9.

- Linn, J. and Pidufala, O. 2009. “The Experience with Regional Economic Cooperation Organizations. Lesson for Central Asia” EDB Eurasian Integration Yearbook, 2009.p.93.

- Linn, Johannes and D. Tiomkin, 2005. “Economic Integration of Eurasia: Opportunities and Challenges of Global Significance" Studies\&Analyses No. 298, In Proceedings of International Conference 'Europe after the Enlargement' Center for Social and Economic Research, Warsaw, 8-9 April.p.1-46.

- $\quad$ Roy, J. And Banerjee, P. 2010. "Connecting South Asia :The centrality of Trade Facilitation for Regional Economic Integration” BeyondSAFTA. p.110.

- Tumbarello, P. 2005. "Regional Trade Integration and WTO Accession: Which is the Right Sequencing ?, An Application to the CIS", IMF, Working Paper, May.p.7.

- UN, 2005. "Building Trade Partnerships in the CIS Region", Document for Information, Trade /2005/17, p.1-18.

- UNCTAD, http://www.unctad.org/Templates/Page.asp?intItemID=1889\&lang=1

- UNDP,http://europeandcis.undp.org/poverty/trade/show/6E1143B5-F203-1EE9B3A7671EB41CA8A3

- Vinokurov, E.,Jadraliyev, M. And Scherbanin, Y. 2009. “The EurAsec Transport Corridors EDB Industry Report”, EDB Eurasian Integration Yearbook 2009. P.186240.

- WTO, http://www.wto.org/english/thewto_e/whatis_e/tif_e/org6_e.htm 